\title{
"If Music is Not a Memory, then what is it?": on the Modern Approach to Musical Memory in Azio Corghi's Creations
}

\author{
Liudmila V. Gavrilova* \\ Krasnoyarsk State Institute of Arts \\ Krasnoyarsk, Russian Federation
}

Received 29.01.2020, received in revised form 18.05.2020, accepted 10.06.2020

\begin{abstract}
The article draws attention to the music of Azio Corghi (b. 1932), a modern Italian composer, hardly known in Russia. His artistic world is organically integrated into one of the characteristic features of modern culture: its inextricable link with the memory of the past. The composer demonstrates his own, original approach to musical memory - an artistic dialogue with it through the use of excerptions from various works of the past. According to the composer it allows him to "re-discover and re-read the past in the spirit of modernity". This Corghi's method is defined in the article with the help of the term riletture (Ital. re-reading), invented by the Italian musicologist Raffaele Mellace. Among a large number of works of this kind, as a specific example, the author considers the dramatic cantata "...fero dolore" - on Pianto della Madonna and Lamento d'Arianna by Claudio Monteverdi, for female voice, viola (oboe d'amour), percussion and string instruments.
\end{abstract}

Keywords: modern music, memory, A. Corghi's creations, excerption, riletture, cantata "...fero dolore".

Research area: culture studies, art.

Citation: Gavrilova, L.V. (2020). "If music is not a memory, then what is it?": on the modern approach to musical memory in Azio Corghi’s creations. J. Sib. Fed. Univ. Humanit. Soc. Sci., 13(6), 1038-1045. DOI: $10.17516 / 1997-1370-0579$.

(C) Siberian Federal University. All rights reserved

* Corresponding author E-mail address: mgavrilova55@gmail.com 
The eminent contemporary scientists (among them D. Likhachev, Yu. Lotman, apologist for postmodernism Umberto Eco) emphasize the inseparable connection of modern culture with its memory of the past. "Complex synthesis ... of the present and the past demonstrates a mechanism of the culture, apperceived by modern researchers and defined through the concept of memory" (Lobanova, 1990), - Marina Lobanova joins them. It seems like modernity strives to master and absorb the entire vast experience of human history. Here is one of the most frequently used Umberto Eco's quotes from the preface to his novel "The Name of the Rose", where he reflects on postmodernism as a kind of response to modernism: "The past, since it cannot really be destroyed, because its destruction leads to silence, must be revisited" (Korobeinikova 2003). Similar statements are found in quotes of many other composers of the second half of the 20th century:

$\mathrm{K}$. Penderecki: "My goal [...] is not to move forward at any cost, resulting perhaps the destruction of music in general, but the discovery of new sources of inspiration in the past" (Ivashkin, 1983).

One of L. Nono's lectures in Darmstadt was titled "History and Presence in the Music of Today."

"If music is not a memory, then what is it?" - says the Italian composer Azio Corghi, demonstrating in his work one of the possible modern approaches to musical memory - artistic dialogue with it.

Here are just a few words about this musician, whose name is almost unknown in Russia. Over the past three decades his works have occupied not only one of the most significant places among the works of Italian composers of the late 20th century, but also gained recognition in the modern musical world of Europe.

Azio Corghi (b. 1937) belongs to a group of composers, which is classified by Russian researchers of Italian music as "generation of the $30 \mathrm{~s}$ ". This, so to speak, is the fourth generation of Italian composers of the 20th century. It appeared after Malipiero, Respighi and Casel-

\footnotetext{
1 This statement belongs to A. Corghi, it is cited from personal electronic correspondence of the author of this article with the composer.
}

la (who were revitalizing traditions of Italian instrumental music), Dallapiccola and Petrassi (who were implementing dodecaphony), Luciano Berio, Bruno Maderna and Luigi Nono, who represent not just Italian, but also the first-line names of the world avant-garde. The path of Azio Corghi in the world of musical composition is similar to the fate of his contemporaries - Sylvano Bussotti and Niccolò Castiglioni. All of them went through an active path of experiments under the influence of the ideas of Darmstadt summer courses. In 1967, at the Ricordi-RAI competition, which was headed by Goffredo Petrassi, Corghi won the first prize with his composition "Intavolature" for orchestra. In 1971 he was an Associate Professor of the experimental course of composition, and in 1978 he headed the Department of composition at the Conservatory "G.Verdi" in Milan.

The real recognition came to him after the premiere of the opera "Blimunda" (1989), staged in Milan in Teatro Lirico (1989), Teatro alla Scala (1990), in Lisbon (1991), in Turin (1992). It was written based on the novel of the Nobel prize winner Portuguese writer José Saramago "Memoirs of the Convent", and for it Corghi got a special prize - "Premio S.I.A.E per Lirica" 2 . Since that time, the works of A. Corghi have taken a permanent place in concert and theater halls both in Italy and abroad. A catalogue of Corghi's works, compiled by the publishing house Casa Ricordi, is as numerous as diverse. But I would like to draw attention to one seemingly external feature of the catalogue (Corghi, 2017) - the wide presence of a number of names, where together with the name of A. Corghi, appear the names of the greatest masters of the past: Giuseppe Verdi and Gioachino Rossini, Claudio Monteverdi and Wolfgang Amadeus Mozart, Gaetano Donizetti and Vincenzo Bellini, George Frideric Handel and Gaspare Spontini. Some of them are delineated as didattiche (edition) and revizioni critica, which is quite natural, because throughout the

\footnotetext{
S.I.A.E (Società Italiana degli Autori ed Editori) - Italian society of authors and publishers, which is associated with the protection of copyright, and also holds competitions, establishes and awards prizes for works in different types of art music, film, theater, fine arts and literature, etc. In particular, the award "S.I.A.E per Lirica" is given to the creators of operas, oratorios, ballets and other musical and theatrical works.
} 
20th century, through the joint efforts of composers, musicologists, musicians-performers works of Italian composers of the past were actively involved in concert life, and much had to be rediscovered - such as music C. Monteverdi, A. Vivaldi. Other works represent the author's scores, where Corghi uses quotes from various works of the past, which allow him, as he defines it, "to rediscover and re-read the past in the spirit of modernity." Italian musicologist Raffaele Mellace outlined this method as riletture (it. re-reading) ${ }^{3}$. There are quite a lot of such works in the creative portfolio of A. Corghi. The composer himself emphasizes that this is not a transcription (!), but a modern approach to musical memory (Mellace R.). He uses the experience of his predecessors and includes it in the conditions of a new artistic experiment with a new meaning. In one of his interviews (which is referred to by the publishing house Ricordi), Corghi stated that he was pertained "to a way of living a story specific for musicians like Berio or Ligeti."

In this regard, we can recall the statement of L. Berio: "I have long intended to undertake a study of the musical composition of the past. A creative study, which would be at the same time analysis, commentary and continuation of the original. This is consistent with my principle: the best way for a composer to analyze and comment on a piece is to do something with the help of material extracted from this piece. The most fruitful commentary on a symphony or opera has always been another symphony or another opera" (Kirillina, 1995). Berio demonstrates experience of such a creative research in the opera "La vera storia" - a kind of paraphrase of Verdi's “The Troubadour" (1977-78).

Probably, in this vein we can consider the appearance among the opera works of A.

\footnotetext{
3 Here is used the term from the text of the booklet, which is intended for demonstration certificate of deposit at publishing house Casa Ricordi - "Le rispondo con le Note di copertina, scritte dal musicologo Raffaele Mellace, per un CD dimostrativo di CASA RICORDI", where all the works of the Italian composer are published. A fragment of the text was sent by Azio Corghi to the author of the article in a letter dated 22.01.2006: "Questo CD racchiude alcuni esempi delle "riletture" che Azio Corghi ha dedicato alle opere della grande scuola melodrammatica" ("This disc presents some examples of "re-readings" by Azio Corghi, which are dedicated to the works of the great masters of the Italian opera school ").
}

Corghi such names as "Isabella" (1996) - a teen-opera based on "L'Italiana in Algeri" by G. Rossini, A. Corghi's scenario by A. Anelli's libretto, for voices (singing and rock), a choir, a rock band, an orchestra and electronic instruments; "Rinaldo \& C." (1997) - a baroccopera based on "Rinaldo" by G.F. Handel (A. Corghi's scenario by A. Hill's libretto, translated by G. Rossi, for voices, a choir [an extended vocal octet] and an orchestra. In these works the composer is close enough to the originals in relation to musical material and composition, but in a number of others he enters into a frank polemic dialogue with the works of the past, using only musical quotations from the great works. For example, the opera "Il dissoluto assolto" - "Justified libertine", which was created by demand of the Milan theater La Scala in 2006. The opera by W.A. Mozart and Da Ponte "Il dissoluto punito, ossia Il Don Giovanni" ("The Libertine Punished, or Don Giovanni") is chosen as the object. Libretto represents again a result of collaboration between Corghi and Saramago. The idea organically fits into the context of one of the most interesting trends in contemporary art, aimed at the deheroization of artistic idols of previous eras: "the humanity as if leaves, laughing its ... past, offering a series of 'reduced' and deheroized to vulgarization figures of Faust and Mephistopheles," - writes G. Iakusheva in her article "Deheroized Faust of the 20th century" (Iakusheva, 1999). We can certainly add Don Juan to this line, the hero of the story "The Confession of Don Juan" written by Karel Capek, and Corghi's operas.

Here is a fragment of J. Saramago's letter, written to the composer, in the period of work on the libretto4: "The only way to 'beat' Don Juan is to deny his amorous conquests in spite of any truth, like: Don Juan is a liar, he has not seduced a single woman in all his life. And when poor Don Juan, trying to protect and defend himself, orders Leporello to show a remarkable catalogue, we see that all his sheets have become white (clean)... That's the way our Don Juan would be defeated, humiliated, despised by Giovanni”.

\footnotetext{
4 Correspondence was provided to the author of the article by the composer A. Corghi.
} 
This thesis determined the organic nature of using Corghi as a citation of famous Leporello's aria with a list. This list is replaced by Elvira with an empty catalogue. And at the end of the opera a brief motive from Basilio's aria about libel sounds - as a kind of mocking summary. Interestingly, the plot of the opera occurs from the last episode of the Mozart's opera - appearance of Donna Elvira and then the Commander's statue, being its continuation and a kind of parody. Using Berio's expression, it is possible to say, that the composer actually writes an other opera as his own commentary on it.

The same can be said about the opera "Jocasta", which was ordered for the Teatro Olimpico in Vicenza for the anniversary celebrations dedicated to the architect of this theater Andrea Palladio. In 1585 for its opening there was staged a play "Oedipus the King" with the music by Venetian composer A. Gabrieli. In the 21st century in the year of the 500th anniversary of the great master Corghi's opera, which in the plot is a continuation of the story of Oedipus, was performed. Blind Oedipus is in prison, Jocasta comes to him and tells about the tragedy that befell their children, she is ready to stay with him and become "his eyes".

No less interesting is the polemical dialogue with the Holy Scripture in the cantata "The Death of Lazarus", based on one of the final episodes of the Saramago's novel "The Gospel According to Jesus Christ". The hero of Corghi does not resurrect Lazarus, he is stopped by the words of Mary.

"And Lazarus would rise, because God wanted so, but at the last minute - really last and ultimate - Mary Magdalene put her hand on his shoulder and said these words: "No one on earth has sinned so hard to die twice ... and Jesus came and dropped his hands, weeping" (Saramago, 2006).

One of the striking examples of creative dialogue with the subjects and works of the past is the cantata. "... fero dolore" ("...searing grief") - based on Claudio Monteverdi's Pianto della Madonna (Madonna's Lament) and Lamento d'Arianna (Ariadne's Lament), for a female voice, the oboe d'amore, percussion and strings. Its premiere in 2006 took place during the festival "Siberia-Italy" in Krasnoyarsk, anticipating the Italian premiere".

Music of Monteverdi becomes an object of "riletture" - the term invented by Raffaele Mellace, which means repeated readings. In 1608 the opera L'Arianna premiered in Mantua, all the music for which is lost apart from Lamento d'Arianna, which remained thanks to the publication in the book of madrigals in 1621. In 1640 the composer on the basis of this Lamento created and published Pianto della Madonna. Corghi uses this material in the edition of 1645 in the vocal part as an accurate citation.

The composition of the cantata is a 3-part structure with a prologue and an epilogue, the code section of which is called the finale (Corghi, 2005). Its basic principle - the alternation of instrumental and vocal-instrumental sections - reminds of the composition of cross-cutting scenes in operas of Monteverdi, where the orchestral ritornello has an important role, framing and dividing in pieces vocal stanzas. This is probably why the instrumental sections, that delineate the units, Corghi calls "ritornelli". Within parts of instrumental solo alto - intermezzo - are divided by vocal monologues and dialogues of heroines - Ariadne and Maria. The instrumental introduction opens the cantata - its thematic material, but in the mirror reflection, completes the work. (Scheme 1)

In the vocal part of the vocal-instrumental sections Corghi uses a citation that includes 6 parts of Lamento d'Arianna (according to S. Skrebkov, there are 10 parts in $i^{5}$ ). In the prologue two female figures are exposed - Ariadne and Maria. Their inner emotional state is common: "endless sorrow" of a woman's heart, who has lost her lover and beloved son. Therefore, the first part of the monologue is repeated twice: first sounds "original" - Lamento d'Arianna, then Maria enters with the same theme of Monteverdi's Lamento. Further, in the first part of the cantata the second and the third parts of

\footnotetext{
The scheme of the monologue is given by S. Skrebkov in the book "Artistic principles of musical styles" (M, 1973, p. 155). A. Corghi used edition Madrigali di Claudio Monteverdi (G. Francesco Malipiero) UNIVERSAL EDITION.
} 
the monologue are used, in the second - the fourth, in the third - the fifth, in the epilogue the sixth.

Specifics of "riletture", if we use R. Mellace's term, can be formulated as follows: "While belcanto keeps seducente riconoscibilità (like diplomatic immunity) in life citation, timbre and instrumental context in which belcanto plunges, creates intrigue in reality". One of the materials that characterize the peculiarities in A. Corghi's music uses the physical notion - diffraction (literally meaning "breaking into pieces, inflexion of obstacles by sound waves"). If one applies this term to describe a method of "riletture", the citation is actually subjected to diffraction.

Monteverdi vocal lines remain intact. (Example 1) The Instrumental accompaniment of the vocal part - the diffraction itself - is directly related to the musical material of the cited source. The dominance of the d-moll key predetermines the preservation of the melodic and harmonic logic of basso continuo part of Monteverdi's Lamento in the lower voices - the cellos and the double bass. In other voices different techniques are used: duplication of the vocal part, prefacing the main motives, the effect of "echo", their simulation, counterpoint transitions, dissonant intensification of the vertical. I must say that the texture of the orchestral accompaniment is extremely variable. Motive combinatorics is combined with active and diverse rhythmic work, as well as the diversity of techniques of playing stringed instruments. This, of course, affects the tendency of Corghi to a game logic. Emphasizing the theatrical nature of the composer's musical thinking, Italian researchers emphasize his "clear taste for ludus".

The composer freely varies the instrumental composition, continuously applying divisi in the strings parties: in the prologue, the orchestra is used without violins, in the first part, on the contrary, at first only violins and double bass, then a full orchestra. Later on Corghi also

\footnotetext{
6 Here is a translation of the letter from the A. Corghi from 22.01.2006 to the author of the article, where the composer quotes the text from the booklet "Le rispondo con le Note di copertina, scritte dal musicologo Raffaele Mellace, per un CD dimostrativo di CASA RICORDI".
}

variedly combines parties, making timbre-register the originality of the sound.

The purely instrumental sections of ritornelli and intermezzo - at first glance, are the exact antithesis of vocal-instrumental sections, different stylistic space. Its organization obviously has an atonal logic, there is the dominance of the sharply dissonant, hard sounding, incredibly sophisticated rhythm. However, a closer study of the score leads to the conclusion that the main thematic elements of the musical "fabric" are borrowed from Monteverdi's Lamento. The initial motive of Lamento acquires a cross-cutting role, becoming a kind of leitmotif of the cantata. A vivid example is $\mathrm{Ri}$ tornello II. (Example 2) In Addition, the function of the fundamental structural elements is assumed by the intervals that make up this motive: small second, its circulation big septima and tritone. In the instrumental sections they structure both vertical and horizontal, performing in various combinations and combining with different methods of sound production. Thereby the thematic level of unity is achieved, which is inherent in the artistic world of the cantata.

The fact that Corghi combines both versions of Monteverdi in his work deserves a special discussion. Along with the ancient mythological theme of the abandoned Ariadne, there is the theme of the grieving the Virgin Mary. Thus, in the cantata, the composer combines subjects belonging to different cultural epochs, intertwines the religious history with the mythological one. I will add that there is a single female singer - mezzo-soprano; she sings Ariadne's part in Italian, and Maria's part in Latin. Thus, the soloist must constantly switch from one role to another. Nevertheless, it happens quite naturally, aided by the fact that the heroines experience quite the same emotional state and have consolidated system of feelings and thoughts. This unity is emphasized by the continuing citation in the vocal parts (even in the dialogical sections) and, accordingly, by the dominance of a single style of performance Monteverdi's stilo concitato. Their unification can be considered as a feature characteristic of postmodern literature practice, defined as "multi-temporal simultaneity". On the other 
hand, there is an obvious intertextual connection between the plots.

The source text, from which the historical perspective is built, is the Lamento d'Arianna from the C. Monteverdi's opera, from the standpoint of intertext, it is endowed with the ability to "read" the story. In terms of the plot, thanks to the citation, the composer turns us to the ancient era and declares the theme of suffering. It is this theme that involves in its associative field the Christian idea of suffering associated with the image of the the Virgin Mary. Thus, "multi-temporal fragments" in history are being ordered into a single "simultaneity". In this regard, the title of one of the articles devoted to A. Corghi is indicative: "Dialogue in time: Azio Corghi and Italian composers of the past." In the dialogical intertextual connection there are two plots relating to two different epochs, in a kind of stylistic dialogue comes Monteverdi's quote and modern musical Corghi's thinking, vocal and instrumental sections of the cantata, in the dialogue of "multi-temporal simultaneity" coexist Ariadne and Maria. In the prologue and part 1 the solo monologues of Ariadne and Maria follow one after another, in parts 2 and 3 their replicas form a dialogical structure.

In connection with the specific role of solo alto intermezzo another dialogue also attracts attention. If the orchestra and the soloist are located on the stage, the violist moves (as well as the performer on percussion instruments) around the hall. This disposition is indicated by the author in the score and has an important meaning. The composer explains, that "the soloist-instrumentalist (alto) can assume the role of both male characters Teseo-Cristo". Thus, alto embodies the conditional existence of Teseo and Cristo, to whom the heroines constantly turn to and with whom they initiate dialogues. His movements in the process of execution, on the one hand, seem to symbolize the loss in the space of the past, on the other hand, if you connect the placement points during performance, you get a cross. Thus, at the level of artistic content we can talk about combining the idea of suffering, endless sorrow with the idea of the Christ's passion.

Interestingly, the alto completes his movements around the hall, finding himself on the stage next to the soloist (riturnello IV) - as if the journey of Teseo and Cristo in time and space lead to those people, to whom they have caused so much suffering. But this seems to have one more meaning - a certain harmonization of the artistic space, it is not by chance that in this section the musical language in the part of the alto softens, the tonality establishes, the sharpness of dissonant sound disappears. However, the finale is still tragic.

"Look where my cruel fate has led me!" Ariadne exclaims. "How much pain brought me my love and loyalty! And it awaits everyone, who love and believe, too!"

And here the composer introduces another quote - this time from a romantic opera - the theme of the dying Violetta from Verdi's "La Traviata", and Corghi retains the original orchestration. The quote sounds like in Verdi's opera in the high register of the first and second violins (ppp). The appearance of this theme as if captures the very highest point of suffering, which may be followed only by death...

Thus, the development of the cantata goes to a new level of content, to a different historical parallel, deepening the semantic perspective of the cantata's finale, where in the last remarks sound the words from the title "...fero dolore" (“...searing grief”).

"The value of musical creativity, - according to A. Corghi, - cannot be determined exclusively by linguistic and technical means. It is determined by the essence of the idea, the depth of thought and the ethics that support it." The idea of the cantata "...fero dolore" - the infinity of the pain of the suffering female heart is revealed in the broad historical perspective of the artistic experience of mankind. "If music is not a memory, then what is it?" let us repeat the words of Azio Corghi.

\footnotetext{
7 This statement belongs to A. Corghi, it is cited from personal electronic correspondence of the author of this article with the composer.
} 


\section{References}

Ivashkin, A. (1983) Kshishtof Penderetskii [Krzysztof Penderecki]. Moscow, 126 p.

Kirillina, L. (1995) Liuchano Berio [Luciano Berio] XX vek. Zarubezhnaia muzyka [The 20th century. Foreign Music]. Issue2. Moscow, Muzyka, 11-57.

Korobeinikova, E. (2003) Simfonia L. Berio v situazii "dialoga kultur" [Symphony by L. Berio in the situation of "dialogue of cultures"]. Prinoshenie muzyke XX veka [Offering for music of the 20th century]. Sb. st. Ekaterinburg. Ural, 107-125.

Lobanova, M. (1990) Muzykalnyi stil i zhanr: istoria i sovremennost [Musical style and genre: history and modernity]. Moscow, Soviet composer, $312 \mathrm{p}$.

Saramago, J. (2006) Evangelie ot Iisusa. [The Gospel of Jesus]. Moscow, Machaon. 446 p.

Iakusheva, G. (1999). Degeroizirovannyi Faust XX veka [Deheroized Faust of the 20th century]. Getevskie chteniia [Goethe's readings]. Moscow, 31-49.

Corghi, A. (2017) Catalogo delle pubblicate de Casa Ricordi - BMG Ricordi S.p.A., Milano, Ricordi. Available at: http://www.ricordi.com/-/media/Files/PDF/Ricordi/Catalogue/Catalogo_Azio_Corghi_-2017 (accessed 20.03.2018)

Corghi, A. (2005) “...fero dolore”. Cantata drammatica per voce femminile, viola, percussion, archi. Partiture. Ricordi, Milano.

Mellace, R. Leading contemporary Italian composer. This article was provided by the composer to the author of the article in 2010 with reference to the Internet resource http://www.tourdates.co.uk/azio-corghi, which is currently inactive. 
«Если музыка не является памятью,

то чем же она является?»:

о современном подходе к музыкальной памяти

в творчестве Ацио Корги

\section{Л.В. Гаврилова}

Красноярский государственный институт искусств

Российская Федерачия, Красноярск

Аннотация. В статье привлекается внимание к творчеству мало известного в России современного итальянского композитора Ацио Корги (р. 1932). Его художественный мир органично встраивается в одну из характерных особенностей современной культуры: ее неразрывной связи с памятью о прошлом. Композитор демонстрирует собственный, оригинальный подход к музыкальной памяти художественный диалог с ней благодаря использованию цитат из различных сочинений прошлого. Это, по словам композитора, позволяет ему «вновь открывать и перечитывать прошлое в духе современности». Этот метод работы Корги определяется в статье при помощи термина riletture (ит. повторные чтения), принадлежащего итальянскому музыковеду Рафаэлю Меллаче. Среди достаточно большого количества произведений подобного рода в качестве конкретного примера автором рассматривается драматическая кантата “...fero dolore” - на Плач Мадонны и Ламенто Ариадны Клаудио Монтеверди, для женского голоса, альта (гобоя д’амур), ударных, струнных.

Ключевые слова: современная музыка, память, творчество А.Корги, цитата, riletture, кантата “...fero dolore"

Научная специальность: 17.00.00 - теория и история искусства. 